\title{
ANALISIS TINGKAT AKURASI ALGORITMA BACKPROPAGATION DALAM PREDIKSI PRODUKSI UBI KAYU DI PROVINSI INDONESIA
}

\author{
Nuraysah Zamil Purba ${ }^{1}$, Deviana Sitompul ${ }^{2}$ \\ Program Studi Teknik Informatika, STIKOM Tunas Bangsa Pematangsiantar. \\ Jln. Sudirman Blok A No 1,2 dan 3 Pematangsiantar 21111 - Indonesia \\ nuraysah7388@gmail.com, devianasitompul821@gmail.com
}

\begin{abstract}
Cassava is one type of food that is widely consumed by the people of Indonesia. In addition to the typical taste, cassava is often processed by the community into a cake or snacks that diverse. According to the statistical report of cassava agriculture in Indonesia from 2005-2015 experience up and down. In order to improve the cassava in Indonesia, it is necessary to make a prediction for the coming year so that the government will have a reference to immediately make the right policy to increase the production of cassava in Indonesia to prevent the increase of cassava import quantity. This study aims to determine the development of cassava production in Indonesia, in the hope that it can be used as a reference to increase the production and productivity of cassava. Data used in this research is data of cassava production in province of Indonesia year 2005-2015, algorithm used is Artificial Neural Network Backpropagation. Data analysis was done using Matlab 2011b. This research uses 5 architecture that is 5-8-1, 5-10-1, 5-15-1, 5-18-1, 5-20-1 but the best architecture is 518-1 with percentage accuracy $94 \%$ and MSE value of 0.007227812. This model is well used to predict cassava in the province of Indonesia.
\end{abstract}

Keywords: Analysis, Accuracy, Backpropagation, Prediction, Cassava

\begin{abstract}
Abstrak
Ubi kayu merupakan salah satu jenis bahan pangan yang banyak dikonsumsi oleh penduduk Indonesia. Selain rasanya yang khas, ubi kayu sering diolah oleh masyarakat menjadi kue atau jajanan yang beraneka ragam. Menurut laporan statistik pertanian ubi kayu di Indonesia dari tahun 2005-2015 mengalami naik turun. Untuk mengupayakan peningkatan ubi kayu di Indonesia, perlu dilakukan yang namanya prediksi untuk tahun yang akan datang sehingga nantinya pemerintah memiliki acuan untuk segera membuat kebijakan yang tepat dalam upaya peningkatan produksi ubi kayu di Indonesia untuk mencegah peningkatan jumlah import ubi kayu. Penelitian ini bertujuan untuk mengetahui perkembangan produksi ubi kayu di Indonesia, dengan harapan dapat dijadikan referensi untuk turut meningkatkan produksi dan produktivitas ubi kayu. Data yang digunakan pada penelitian ini adalah data produksi ubi kayu di provinsi Indonesia tahun 20052015, algoritma yang digunakan adalah Jaringan Saraf Tiruan Backpropagation. Analisa data dilakukan dengan menggunakan Matlab 2011b. Penelitian ini menggunakan 5 arsitektur yaitu 5-81, 5-10-1, 5-15-1, 5-18-1, 5-20-1 tapi arsitektur yang terbaik adalah 5-18-1 dengan persentase akurasi 94\% dan nilai MSE sebesar 0,007227812. Model ini baik digunakan untuk memprediksi ubi kayu di provinsi Indonesia.
\end{abstract}

Kata Kunci : Analisis, Akurasi, Backpropagation, Prediksi, Ubi Kayu

\section{PENDAHULUAN}

Ubi kayu merupakan salah satu tanaman utama penghasil pati, selain jagung, sorghum, gandum, beras, sagu, dan kentang, dengan karakteristik masing-masing pati berbeda [1]. Ubi kayu juga merupakan salah satu komoditas tanaman pangan yang menjadi unggulan dan mempunyai potensi dalam pertumbuhan ekonomi Indonesia [2]. Di Indonesia sendiri, ubi kayu termasuk bahan makanan penting setelah padi dan jagung [3]. Pentingnya ubikayu dalam mewujudkan kedaulatan 
pangan di Indonesia adalah karena ubikayu selain berperan dalam pemenuhan kebutuhan sumber karbohidrat untuk substitusi beras, juga untuk diversifikasi pangan. Ubikayu juga dapat dimanfaatkan sebagai sumber pakan, bahan baku industri dan bahan baku bioethanol. Karena begitu pentingnya ubi kayu sebagai salah satu sumber bahan makanan di Indonesia, maka perlu dilakukan tindakan dan langkah yang tepat dari Pemerintah Indonesia, agar produksi ubi kayu tetap stabil dari tahun ketahun.

Pada tabel 1 dapat dilihat data produksi ubi kayu pada tiap provinsi di Indonesia. Berdasarkan tabel 1 bahwa produksi ubi kayu dari tahun 2005 sampai dengan tahun 2015 tidak stabil, kadang produksi nya naik bahkan kadang menurun. Pada daerah-daerah seperti pada provinsi Aceh, Jawa Tengah, Yogyakarta, Bali, Jawa Timur, Nusa Tenggara Timur, Kalimantan Barat, Kalimantan Tengah, Kalimantan Selatan, Kalimantan Timur, Sulawesi Tengah, Sulawesi Utara, Gorontalo, Sulawesi Barat, dan Papua Barat secara umum produksi ubi kayu nya mengalami penurunan. Sedangkan di provinsi-provinsi lainnya relatif menaik.

Tabel 1. Data Produksi Ubi Kayu Di Provinsi Indonesia

\begin{tabular}{|c|c|c|c|c|c|c|c|c|c|c|c|}
\hline Pro & 2005 & 006 & 2007 & 2008 & 2009 & 2010 & 2011 & 2012 & 2013 & 2014 & 2015 \\
\hline$e h$ & & & & & & & & & & & \\
\hline Sumat & & & & & & & & & & & \\
\hline Suntac & & 133095 & & 102285 & 115492 & 193188 & 191946 & 213647 & 218830 & 217962 & 20838 \\
\hline Riau & 16 & 4758 & 5178 & 0772 & 68046 & 5904 & 9480 & 88577 & 103070 & 117287 & 10359 \\
\hline Jambi & 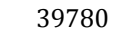 & 40779 & 4 & 5 & 5 & & & & & & 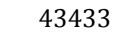 \\
\hline Suma & & 228321 & 1 & 0 & 0 & 29 & 15 & & 165250 & & 21780 \\
\hline Benglu & 4 & 113488 & 4 & 478 & 1 & 47 & 5 & 8 & 3 & 3 & $8032-3$ \\
\hline Lampung & 806254 & 5499403 & 6394906 & 7721882 & 7569178 & 8637594 & 9193676 & 8387 & 8329 & 803 & 738708 \\
\hline Kep. Ban & 19234 & 17264 & 18666 & 19722 & 23332 & 21427 & 13276 & 13469 & 3 & 9 & 35024 \\
\hline Kep. Riau & 3526 & 6899 & 7077 & 9364 & 9180 & 8397 & 7805 & 76 & 0 & 9 & 915 \\
\hline Jawa & 2068981 & 20446 & 40 & 2034854 & 7 & 2014402 & 205 & 2131 & 213 & 225 & 022 \\
\hline $\mathrm{Ja}^{\mathrm{a}}$ & 70 & 820 & 3 & 9 & 99 & 42 & 3 & 38 & 4 & 39 & 3 \\
\hline Di Yogyakarta & 0909 & 1016270 & 976610 & 892907 & 1047684 & 1114665 & 96 & 866357 & 1013565 & 88 & 87336 \\
\hline Jawa ' & 4023614 & 567 & 342 & 3533772 & 637 & 3667058 & 4032081 & 42 & 36 & 36 & 31 \\
\hline Banten & 144110 & 143561 & 117550 & 115591 & 105621 & 118979 & 107052 & 82796 & 07847 & & 7416 \\
\hline Bali & 5808 & 159058 & 174189 & 169761 & 171456 & 163746 & 166291 & 147201 & 1569 & 131 & 86070 \\
\hline at & & & & & 02 & 6 & & & & & 10 \\
\hline Nusa Tenggar & 891783 & 938010 & 794121 & 928974 & 913053 & 1032538 & 962128 & 892145 & 166 & 677577 & 637315 \\
\hline Kalim & 243251 & 250173 & 1630 & 04 & 166584 & 307 & & & & & 17 \\
\hline Kalim & 73866 & 65661 & 76 & 44 & 74670 & 69 & & 46 & 2 & & 45712 \\
\hline Selatan & 80377 & 2389 & 117322 & 119085 & 121656 & 76202 & 4 & 900 & & 92 & 71751 \\
\hline Kalin & & 101249 & 105 & & 125 & 61 & & & & & 53966 \\
\hline 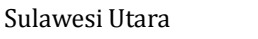 & 68463 & Оटт10 & 1 тिण & 83656 & 77206 & 84084 & & 63187 & 55207 & & TTIL \\
\hline ngah & 2 & 791 & 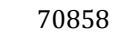 & 1 & 82294 & 28 & 9 & 2 & 1 & 8 & 47295 \\
\hline Sulawesi Selatan & 464435 & 567749 & 514277 & 504198 & 434862 & 601437 & 370125 & 682995 & 43 & 478486 & 565958 \\
\hline Sulawesi Tenggara & 256467 & 238039 & 239271 & 217727 & 226927 & 163350 & 164850 & 175719 & 180680 & 175086 & 175095 \\
\hline Gorontalo & 12211 & 9410 & 7432 & 9215 & 7117 & 6171 & 5910 & 3776 & 4537 & 3987 & 2653 \\
\hline Sulawe & 5 & ? & 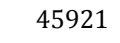 & 9 & 47781 & 68 & & & 52972 & & 24984 \\
\hline Maluku & 5 & 103260 & 10 & 214 & 24442 & 144 & 125 & 11 & 13 & 99 & 134661 \\
\hline Maluku U & 142680 & 123833 & 118354 & 116838 & 106443 & 109033 & 115940 & 116515 & 119799 & 147917 & 120283 \\
\hline Papua Bara & 2589 & 2183 & 1783 & 23072 & 12228 & 25113 & 20440 & 974 & 122 & 11169 & 11181 \\
\hline Papua & 3959 & 7825 & 4450 & 5100 & 36500 & 35531 & 34899 & 36679 & 38901 & 45512 & 46388 \\
\hline
\end{tabular}


Oleh karena itu perlu dilakukan prediksi (peramalan) [4][5][6], terhadap produksi ubi kayu di Indonesia untuk tahun-tahun selanjutnya agar produksi ubi kayu tetap stabil. Salah satu cara yang sering digunakan untuk melakukan prediksi adalah dengan menggunakan jaringan saraf tiruan. Jaringan saraf tiruan (JST) adalah representasi buatan dari otak manusia yang selalu mencoba untuk mensimulasikan proses pembelajaran pada otak manusia. Istilah buatan digunakan karena jaringan saraf ini diimplementasikan dengan menggunakan program komputer yang mampu menyelesaikan sejumlah proses perhitungan selama proses pembelajaran [7][8][9]. Salah satu penggunaan teknik yang baik untuk prediksi adalah penerapan jaringan saraf tiruan Backpropagation, hal ini karena algoritma Backpropagation mampu menghindari kesulitan yang dijelaskan dengan menggunakan aturan belajar yang mirip dengan plastisitas lonjakan waktu yang tergantung pada sinapsis [10][11][12]. Maksudnya bahwa algoritma Backpropagation ini mampu mengatasi ketidakmampuan otak biasa dalam mengingat hal-hal yang sudah pernah terjadi di masa lampau dengan melakukan proses pembelajaran memori.

\section{METODE PENELITIAN}

\subsection{Analisis}

Analisis adalah sebuah kemampuan untuk memecahkan suatu masalah subjek kedalam elemen-elemen konstituen, mencari hubungan-hubungan internal, serta mengatur format-format pemecahan masalah secara keseluruhan yang ada. Analisis data bertujuan untuk membuktikan hipotesis, dan atau menjelaskan fenomena yang menjadi latar belakang penelitian [13][14].

\subsection{Jaringan Saraf Tiruan Backpropagation}

Backpropagation merupakan sebuah metode sistematik untuk pelatihan multiplayer jaringan saraf tiruan. Metode ini memiliki dasar matematis yang kuat, obyektif dan algoritma ini mendapatkan bentuk persamaan dan nilai koefisien dalam formula dengan meminimalkan jumlah kuadrat galat error melalui model yang dikembangkan [15][16]. Backpropagation merupakan algoritma pembelajaran yang terawasi dan biasanya digunakan oleh perceptron dengan banyak lapisan untuk mengubah bobot yang terhubung dengan neuron yang ada pada lapisan tersembunyinya [17][18].

\subsection{Prediksi}

Prediksi adalah memperkirakan suatu hal yang akan terjadi di waktu yang akan datang berdasarkan data-data dimasa yang lampau dianalisah secara ilmiah. Prediksi dapat diartikan sebagai penggunaan teknik-teknik statistik dalam bentuk gambaran masa depan berdasarkan pengolahan angka-angka historis [19]. Definisi lain dari prediksi ialah suatu usaha untuk meramalkan suatu keadaan dimasa mendatang melalui pengujian data-data di masa lalu [20].

\subsection{Tahapan Penelitian}

Adapun tahapan penelitian dalam tulisan ini dalapat dilihat pada gambar 1 berikut. 


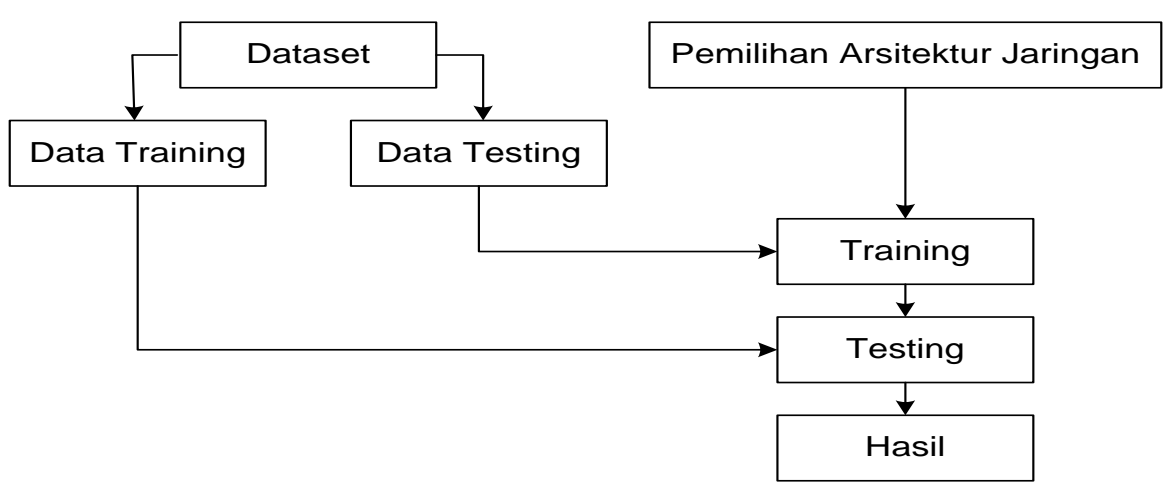

Gambar 1. Tahapan Penelitian

Pada gambar 1 diatas, pertama sekali yang dilakukan ialah pemilihan dataset, dimana dataset yang digunakan adalah data Produksi Ubi Kayu Di Provinsi Indonesia tahun 2005 hingga tahun 2015. Pada dataset ini akan dilakukan praprocessing data untuk membagi data menjadi dua bagian yaitu dataset untuk training dan dataset untuk testing. Tahapan selanjutnya adalah pemilihan arsitektur jaringan untuk memproses data training dan data testing, sehingga akan diperoleh hasil yang terbaik.

\subsection{Data Yang Digunakan}

Data yang digunakan untuk penelitian ini adalah data produksi ubi kayu menurut Provinsi di Indonesia (Dapat dilihat di Tabel 1 pada pembahasan sebelumnya) yang diperoleh dari Badan Pusat Statistik (BPS) Indonesia. Data pada tabel 1 nanti nya akan dibagi menjadi 2 bagian, yaitu data training dan data testing. Data training yang digunakan yakni data tahun 2005-2009 dengan target tahun 2010, sedangkan untuk data testing yang digunakan yakni data tahun 2010-2014 dengan target tahun 2015

\subsection{Normalisasi Data}

Data mentah (data awal) yang telah dikumpulkan harus terlebih dahulu dinormalisasi dengan menggunakan fungsi Sigmoid. Artinya data yang dinormalisasi nanti nya akan menghasilkan nilai antara 0 dan 1 (Tidak boleh 0 dan 1, apalagi lebih dari itu), karena hal itu sudah merupakan ketentuan dari normalisasi. Normalisasi data dilakukan dengan menggunakan persamaan :

$x^{\prime}=\frac{0.8(x-a)}{b-a}+0.1$

Keterangan :

$x^{\prime}=$ Normalisasi data

$x=$ Data yang akan dinormalisasi

$a=$ Data terendah

$b=$ Data tertinggi

Pada tabel 2 dapat dilihat hasil normalisasi data training. Data ini telah dinormalisasi menggunakan fungsi sigmoid (persamaan 1) berdasarkan pada tabel 1, yakni tahun 2005-2009 dengan target tahun 2010. 
Tabel 2. Normalisasi Data Training Tahun 2005-2009 / Target Tahun 2010

\begin{tabular}{|c|c|c|c|c|c|c|}
\hline Provinsi & 2005 & 2006 & 2007 & 2008 & 2009 & Target \\
\hline Aceh & 0,10462 & 0,10398 & 0,10352 & 0,10323 & 0,10429 & 0,10373 \\
\hline Sumatera Utara & 0,14691 & 0,14160 & 0,14031 & 0,16794 & 0,19300 & 0,18358 \\
\hline Sumatera Barat & 0,11025 & 0,11201 & 0,11029 & 0,10915 & 0,11037 & 0,11757 \\
\hline Riau & 0,10353 & 0,10408 & 0,10447 & 0,10438 & 0,10598 & 0,10671 \\
\hline Jambi & 0,10336 & 0,10345 & 0,10382 & 0,10309 & 0,10332 & 0,10334 \\
\hline Sumatera Selatan & 0,11635 & 0,12083 & 0,11358 & 0,11794 & 0,11514 & 0,11449 \\
\hline Bengkulu & 0,10708 & 0,11019 & 0,10680 & 0,10426 & 0,10313 & 0,10374 \\
\hline Lampung & 0,54500 & 0,60923 & 0,69220 & 0,81515 & 0,80100 & 0,90000 \\
\hline Kep. Bangka B & 0,10146 & 0,10127 & 0,10140 & 0,10150 & 0,10184 & 0,10166 \\
\hline Kep. Riau & 0,10000 & 0,10031 & 0,10033 & 0,10054 & 0,10052 & 0,10045 \\
\hline Jawa Barat & 0,29138 & 0,28913 & 0,27784 & 0,28822 & 0,29297 & 0,28632 \\
\hline Jawa Tengah & 0,42202 & 0,42896 & 0,41567 & 0,40776 & 0,44035 & 0,45883 \\
\hline Di yogyakarta & 0,18500 & 0,19384 & 0,19016 & 0,18241 & 0,19675 & 0,20295 \\
\hline Jawa Timur & 0,47249 & 0,44070 & 0,41689 & 0,42710 & 0,39827 & 0,43945 \\
\hline Banten & 0,11303 & 0,11298 & 0,11057 & 0,11038 & 0,10946 & 0,11070 \\
\hline Bali & 0,11411 & 0,11441 & 0,11581 & 0,11540 & 0,11556 & 0,11485 \\
\hline Nusa Tenggara Barat & 0,10829 & 0,10774 & 0,10788 & 0,10601 & 0,10755 & 0,10622 \\
\hline Nusa Tenggara Timur & 0,18230 & 0,18659 & 0,17325 & 0,18575 & 0,18427 & 0,19534 \\
\hline Kalimantan Barat & 0,12221 & 0,12285 & 0,12021 & 0,11763 & 0,11511 & 0,11615 \\
\hline Kalimantan Tengah & 0,10652 & 0,10576 & 0,10594 & 0,10647 & 0,10659 & 0,10678 \\
\hline Kalimantan Selatan & 0,10712 & 0,10731 & 0,11054 & 0,11071 & 0,11095 & 0,10673 \\
\hline Kalimantan Timur & 0,10837 & 0,10905 & 0,10944 & 0,11044 & 0,11132 & 0,10987 \\
\hline Sulawesi Utara & 0,10602 & 0,10731 & 0,10657 & 0,10742 & 0,10683 & 0,10746 \\
\hline Sulawesi Tengah & 0,10414 & 0,10456 & 0,10624 & 0,10618 & 0,10730 & 0,10654 \\
\hline Sulawesi Selatan & 0,14271 & 0,15228 & 0,14732 & 0,14639 & 0,13997 & 0,15540 \\
\hline Sulawesi Tenggara & 0,12344 & 0,12173 & 0,12184 & 0,11985 & 0,12070 & 0,11481 \\
\hline Gorontalo & 0,10080 & 0,10055 & 0,10036 & 0,10053 & 0,10033 & 0,10025 \\
\hline Sulawesi Barat & 0,10493 & 0,10342 & 0,10393 & 0,10475 & 0,10410 & 0,10397 \\
\hline Maluku & 0,10848 & 0,10924 & 0,10947 & 0,10961 & 0,11120 & 0,11305 \\
\hline Maluku Utara & 0,11289 & 0,11115 & 0,11064 & 0,11050 & 0,10954 & 0,10978 \\
\hline Papua Barat & 0,10207 & 0,10170 & 0,10133 & 0,10181 & 0,10081 & 0,10200 \\
\hline Papua & 0,10282 & 0,10318 & 0,10287 & 0,10293 & 0,10306 & 0,10297 \\
\hline
\end{tabular}

Pada tabel 3 dapat dilihat hasil normalisasi data testing. Data ini telah dinormalisasi menggunakan fungsi sigmoid (persamaan 1) berdasarkan pada tabel 1, yakni tahun 2010-2014 dengan target tahun 2015.

Tabel 3. Normalisasi Data Testing Tahun 2010-2014 / Target Tahun 2015

\begin{tabular}{lcccccc}
\hline \multicolumn{1}{c}{ Provinsi } & $\mathbf{2 0 1 0}$ & $\mathbf{2 0 1 1}$ & $\mathbf{2 0 1 2}$ & $\mathbf{2 0 1 3}$ & $\mathbf{2 0 1 4}$ & Target \\
\hline Aceh & 0,10358 & 0,10320 & 0,10310 & 0,10279 & 0,10252 & 0,10230 \\
Sumatera Utara & 0,17859 & 0,19479 & 0,20174 & 0,23192 & 0,22018 & 0,24073 \\
Sumatera Barat & 0,11658 & 0,11648 & 0,11837 & 0,11882 & 0,11874 & 0,11791 \\
Riau & 0,10638 & 0,10669 & 0,10748 & 0,10874 & 0,10998 & 0,10879 \\
\hline
\end{tabular}


ISSN: 2527-5771/EISSN: 2549-7839

http://tunasbangsa.ac.id/ejurnal/index.php/jurasik

\begin{tabular}{lcccccc}
\hline \multicolumn{1}{c}{ Provinsi } & $\mathbf{2 0 1 0}$ & $\mathbf{2 0 1 1}$ & $\mathbf{2 0 1 2}$ & $\mathbf{2 0 1 3}$ & $\mathbf{2 0 1 4}$ & Target \\
\hline Jambi & 0,10321 & 0,10329 & 0,10316 & 0,10267 & 0,10286 & 0,10355 \\
Sumatera Selatan & 0,11369 & 0,11364 & 0,11227 & 0,11415 & 0,11892 & 0,11873 \\
Bengkulu & 0,10359 & 0,10392 & 0,10478 & 0,10518 & 0,10663 & 0,10676 \\
Lampung & 0,85160 & 0,90000 & 0,82982 & 0,82475 & 0,79906 & 0,74275 \\
Kep. Bangka Belitung & 0,10163 & 0,10092 & 0,10094 & 0,10101 & 0,10149 & 0,10282 \\
Kep. Riau & 0,10050 & 0,10045 & 0,10044 & 0,10051 & 0,10055 & 0,10057 \\
Jawa Barat & 0,27511 & 0,27897 & 0,28527 & 0,28591 & 0,29561 & 0,27387 \\
Jawa Tengah & 0,43716 & 0,40454 & 0,43474 & 0,45574 & 0,44600 & 0,41065 \\
Di yogyakarta & 0,19679 & 0,17529 & 0,17518 & 0,18799 & 0,17679 & 0,17579 \\
Jawa Timur & 0,41896 & 0,45073 & 0,46935 & 0,41321 & 0,41620 & 0,37496 \\
Banten & 0,11013 & 0,10909 & 0,10698 & 0,10829 & 0,10725 & 0,10622 \\
Bali & 0,11402 & 0,11424 & 0,11258 & 0,11343 & 0,11125 & 0,10726 \\
Nusa Tenggara Barat & 0,10591 & 0,10633 & 0,10669 & 0,10491 & 0,10783 & 0,10910 \\
Nusa Tenggara Timur & 0,18964 & 0,18351 & 0,17742 & 0,17037 & 0,15875 & 0,15524 \\
Kalimantan Barat & 0,11525 & 0,11209 & 0,11314 & 0,11444 & 0,11657 & 0,11487 \\
Kalimantan Tengah & 0,10644 & 0,10408 & 0,10383 & 0,10332 & 0,10354 & 0,10375 \\
Kalimantan Selatan & 0,10640 & 0,10730 & 0,10761 & 0,10737 & 0,10780 & 0,10601 \\
Kalimantan Timur & 0,10935 & 0,10776 & 0,10697 & 0,10460 & 0,10507 & 0,10447 \\
Sulawesi Utara & 0,10709 & 0,10587 & 0,10527 & 0,10457 & 0,10382 & 0,10361 \\
Sulawesi Tengah & 0,10622 & 0,10701 & 0,10792 & 0,10856 & 0,10714 & 0,10389 \\
Sulawesi Selatan & 0,15212 & 0,13199 & 0,15922 & 0,13749 & 0,14142 & 0,14903 \\
Sulawesi Tenggara & 0,11399 & 0,11412 & 0,11506 & 0,11550 & 0,11501 & 0,11501 \\
Gorontalo & 0,10031 & 0,10028 & 0,10010 & 0,10016 & 0,10012 & 0,10000 \\
Sulawesi Barat & 0,10381 & 0,10392 & 0,10397 & 0,10438 & 0,10237 & 0,10194 \\
Maluku & 0,11234 & 0,11072 & 0,11017 & 0,10828 & 0,10830 & 0,11149 \\
Maluku Utara & 0,10926 & 0,10986 & 0,10991 & 0,11020 & 0,11264 & 0,11024 \\
Papua Barat & 0,10195 & 0,10155 & 0,10062 & 0,10083 & 0,10074 & 0,10074 \\
Papua & 0,10286 & 0,10281 & 0,10296 & 0,10316 & 0,10373 & 0,10381 \\
\hline & & & & & &
\end{tabular}

\section{HASII DAN PEMBAHASAN}

\subsection{Analisis}

Sebelum training dilakukan, terlebih dahulu menentukan nilai parameter yang diinginkan untuk memperoleh hasil yang optimal. Parameter yang digunakan secara umum pada aplikasi Matlab untuk training dan testing dapat dilihat pada kode berikut :

\section{> net=newff(minmax(P),[ Hidden,Target],\{'transig','purelin'\},'traingd');}

//Perintah ini digunakan untuk membentuk jaringan pada Backpropagation dengan hidden layer 19 dan output 1, dengan menggunakan fungsi aktivasi tansig dan purelin serta fungsi pelatihan traingd. $>$ net.IW\{1,1\};

// Perintah ini digunakan untuk melihat nilai bobot awal pada lapisan masukan dan lapisan tersembunyi (bilangan diambil secara acak dari komputer)

> net.b\{1\};

// Perintah ini digunakan untuk melihat nilai bias awal pada lapisan tersembunyi (bilangan diambil secara acak dari komputer)

> net.LW\{2,1\}; 
// Perintah ini digunakan untuk melihat nilai bobot awal pada lapisan tersembunyi dan lapisan keluaran (bilangan diambil secara acak dari komputer)

$>$ net.b\{2\};

// Perintah ini digunakan untuk melihat nilai bias awal pada lapisan keluaran (bilangan diambil secara acak dari komputer)

> net.trainParam.epochs $=10000$;

// Perintah yang dipakai untuk menentukan jumlah epochs maksimum pelatihan

> net.trainParam.goal=0.001;

//Perintah untuk menentukan batas MSE agar iterasi dihentikan. Iterasi akan berhenti jika MSE < dari batas yang ditentukan atau jumlah epoch telah mencapai maksimum sesuai nilai yang diberikan pada perintah net.trainParam.epochs

$>$ net.trainParam.Lr=0.01;

//Perintah yang digunakan untuk menentukan laju pembelajaran (learning rate). Default-nya adalah 0,01. Semakin besar nilai laju pembelajaran, semakin cepat pula proses pelatihan. Akan tetapi jika nilainya terlalu besar, algoritma menjadi tidak stabil dan mencapai titik minimum lokal

> net.trainParam.show $=1000$;

// Perintah yang digunakan untuk menampilkan frekuensi perubahan MSE

> net=train(net,P,T);

// Perintah untuk menampilkan hasil dari data traning dan data testing yang telah di masukkan pada aplikasi matlab

\subsection{Hasil}

Penelitian ini menggunakan 5 arsitektur, antara lain : 5-8-1, 5-10-1, 5-15-1, 5-18-1 dan 5-20-1. Dari kelima arsitektur tersebut, arsitektur yang terbaik ialah 518-1 dengan tingkat akurasi sebesar 94\% serta epoch sebesar 885 iterasi.

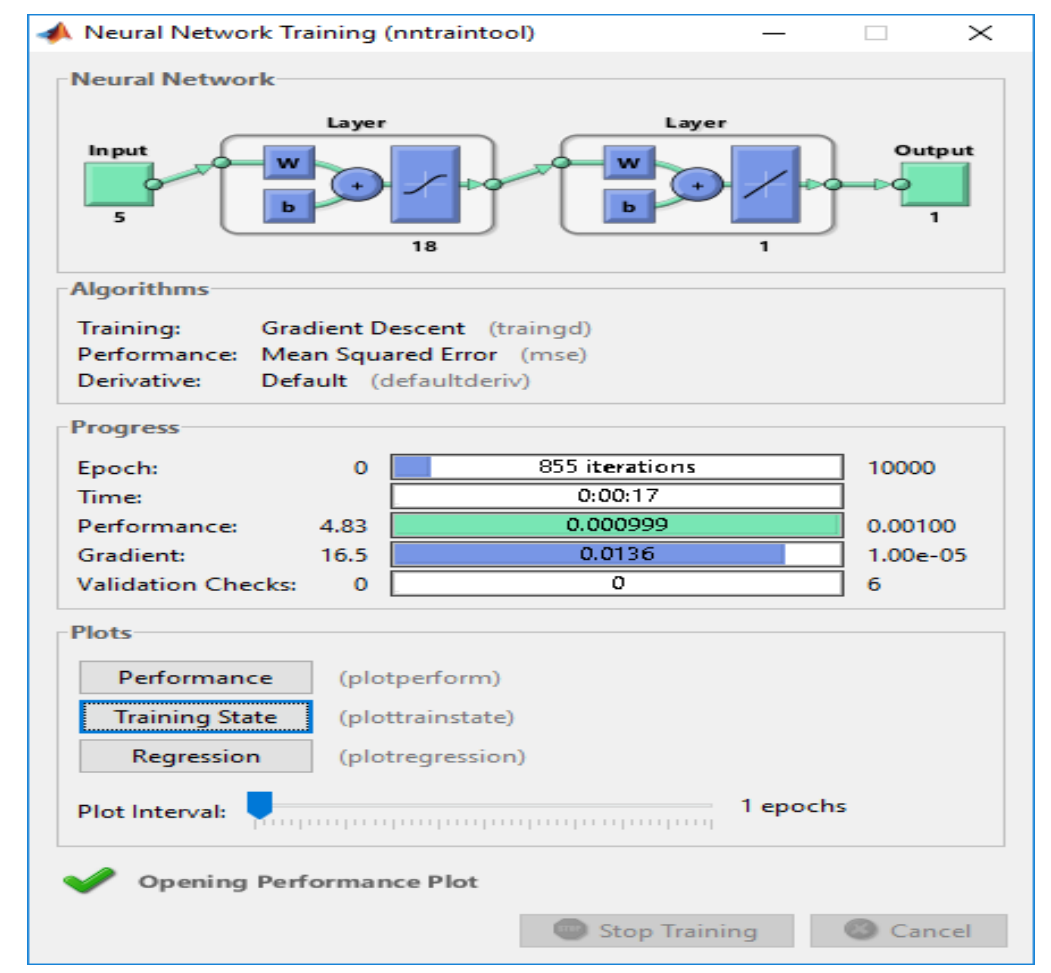

Gambar 2. Data Training Dengan Model Arsitektur 5-18-1

Dari gambar 2 data training dengan model arsitektur 5-18-1 dapat dijelaskan bahwa epoch yang terjadi sebesar 855 iterations dengan waktu yang cukup cepat, yakni selama 17 detik. 


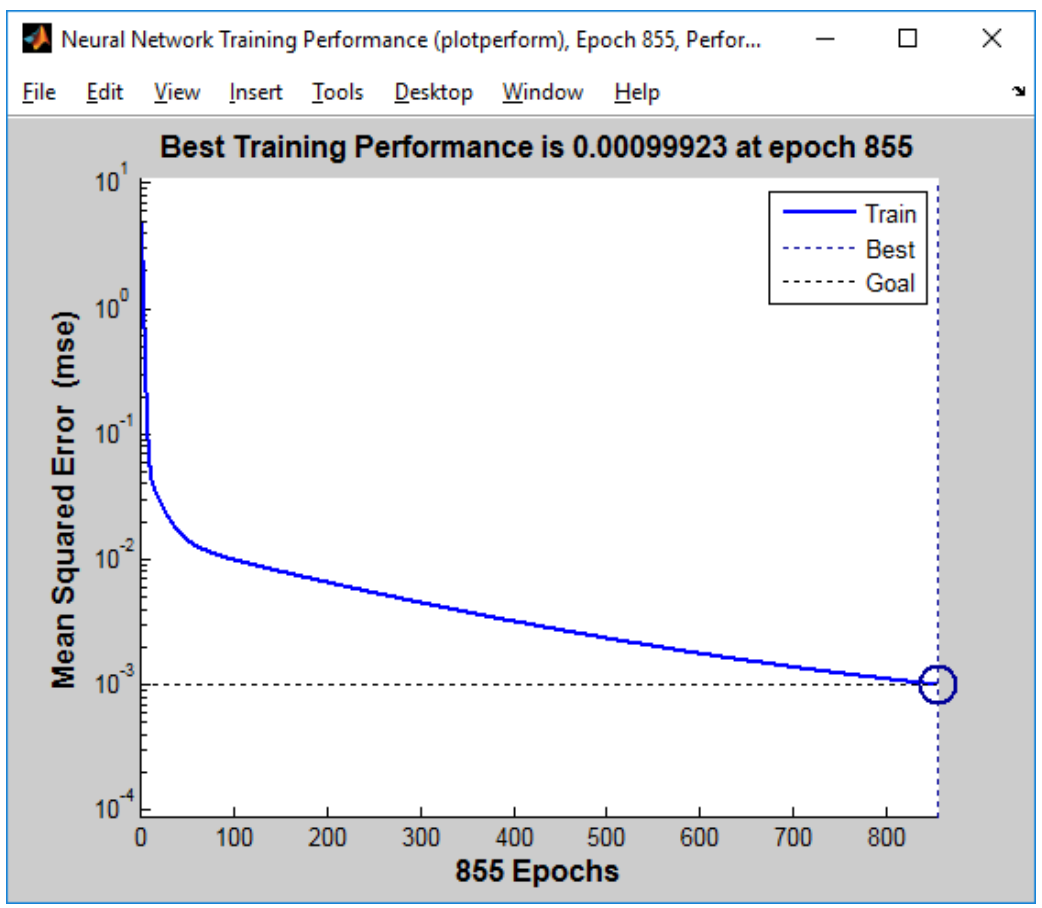

Gambar 3. Best Training Performance Dengan Arsitektur 5-18-1

Berdasarkan gambar 3 dapat dijelaskan bahwa performance pelatihan terbaik adalah 0.00099923 pada epoch 855 . Tabel 4 merupakan hasil akurasi dari model arsitektur terbaik dengan algoritma Backpropagation, yakni 5-18-1. Tabel 4 ini dibuat dan dihitung dengan menggunakan Microsoft Excel.

Tabel 4. Arsitektur Terbaik Algoritma Backpropagation dengan Model 5-18-1

\begin{tabular}{|c|c|c|c|c|c|c|c|c|c|}
\hline \multirow{2}{*}{ No } & \multicolumn{4}{|c|}{ Data Training } & \multicolumn{4}{|c|}{ Data Testing } & \multirow{2}{*}{ Hasil } \\
\hline & Target & Output & Error & SSE & Target & Output & Error & SSE & \\
\hline 1 & 0,10373 & 0,11990 & 0,06368 & 0,00405515 & 0,10230 & 0,12010 & $-0,01780$ & 0,00031667 & 1 \\
\hline 2 & 0,18358 & 0,16390 & $-0,04633$ & 0,00214616 & 0,24073 & 0,24850 & $-0,00777$ & 0,00006034 & 1 \\
\hline 3 & 0,11757 & 0,11550 & $-0,00879$ & 0,00007733 & 0,11791 & 0,11880 & $-0,00089$ & 0,00000080 & 1 \\
\hline 4 & 0,10671 & 0,12100 & $-0,01766$ & 0,00031191 & 0,10879 & 0,12100 & $-0,01221$ & 0,00014917 & 1 \\
\hline 5 & 0,10334 & 0,12050 & $-0,00601$ & 0,00003610 & 0,10355 & 0,12020 & $-0,01665$ & 0,00027724 & 1 \\
\hline 6 & 0,11449 & 0,10640 & $-0,00266$ & 0,00000710 & 0,11873 & 0,11800 & 0,00073 & 0,00000053 & 1 \\
\hline 7 & 0,10374 & 0,11320 & 0,78680 & 0,61905424 & 0,10676 & 0,12160 & $-0,01484$ & 0,00022025 & 1 \\
\hline 8 & 0,90000 & 0,89110 & $-0,78944$ & 0,62321766 & 0,74275 & 0,75540 & $-0,01265$ & 0,00015998 & 1 \\
\hline 9 & 0,10166 & 0,12130 & $-0,02085$ & 0,00043467 & 0,10282 & 0,12140 & $-0,01858$ & 0,00034530 & 1 \\
\hline 10 & 0,10045 & 0,12150 & 0,16482 & 0,02716568 & 0,10057 & 0,12140 & $-0,02083$ & 0,00043405 & 1 \\
\hline 11 & 0,28632 & 0,28860 & 0,17023 & 0,02897865 & 0,27387 & 0,40250 & $-0,12863$ & 0,01654530 & 1 \\
\hline 12 & 0,45883 & 0,43920 & $-0,23625$ & 0,05581221 & 0,41065 & 0,71660 & $-0,30595$ & 0,09360797 & 1 \\
\hline 13 & 0,20295 & 0,11250 & 0,32695 & 0,10689564 & 0,17579 & 0,12040 & 0,05539 & 0,00306781 & 0 \\
\hline 14 & 0,43945 & 0,50910 & $-0,39840$ & 0,15872460 & 0,37496 & 0,69700 & $-0,32204$ & 0,10371170 & 1 \\
\hline 15 & 0,11070 & 0,11370 & 0,00115 & 0,00000131 & 0,10622 & 0,11600 & $-0,00978$ & 0,00009556 & 1 \\
\hline
\end{tabular}


http://tunasbangsa.ac.id/ejurnal/index.php/jurasik

\begin{tabular}{|c|c|c|c|c|c|c|c|c|c|}
\hline \multirow{2}{*}{ No } & \multicolumn{4}{|c|}{ Data Training } & \multicolumn{4}{|c|}{ Data Testing } & \multirow{2}{*}{ Hasil } \\
\hline & Target & Output & Error & SSE & Target & Output & Error & SSE & \\
\hline 16 & 0,11485 & 0,11840 & $-0,01218$ & 0,00014847 & 0,10726 & 0,11420 & $-0,00694$ & 0,00004815 & 1 \\
\hline 17 & 0,10622 & 0,11880 & 0,07654 & 0,00585904 & 0,10910 & 0,12010 & $-0,01100$ & 0,00012090 & 1 \\
\hline 18 & 0,19534 & 0,09490 & 0,02125 & 0,00045149 & 0,15524 & 0,05780 & 0,09744 & 0,00949492 & 0 \\
\hline 19 & 0,11615 & 0,10730 & $-0,00052$ & 0,00000027 & 0,11487 & 0,12000 & $-0,00513$ & 0,00002635 & 1 \\
\hline 20 & 0,10678 & 0,11990 & $-0,01317$ & 0,00017335 & 0,10375 & 0,11960 & $-0,01585$ & 0,00025129 & 1 \\
\hline 21 & 0,10673 & 0,12260 & $-0,01273$ & 0,00016202 & 0,10601 & 0,11940 & $-0,01339$ & 0,00017917 & 1 \\
\hline 22 & 0,10987 & 0,11960 & $-0,01214$ & 0,00014728 & 0,10447 & 0,11710 & $-0,01263$ & 0,00015961 & 1 \\
\hline 23 & 0,10746 & 0,11840 & $-0,01186$ & 0,00014062 & 0,10361 & 0,11830 & $-0,01469$ & 0,00021581 & 1 \\
\hline 24 & 0,10654 & 0,12200 & 0,03340 & 0,00111557 & 0,10389 & 0,11980 & $-0,01591$ & 0,00025326 & 1 \\
\hline 25 & 0,15540 & 0,09490 & 0,01991 & 0,00039636 & 0,14903 & 0,14730 & 0,00173 & 0,00000300 & 1 \\
\hline 26 & 0,11481 & 0,11330 & $-0,01305$ & 0,00017043 & 0,11501 & 0,11800 & $-0,00299$ & 0,00000894 & 1 \\
\hline 27 & 0,10025 & 0,12110 & $-0,01713$ & 0,00029345 & 0,10000 & 0,12120 & $-0,02120$ & 0,00044944 & 1 \\
\hline 28 & 0,10397 & 0,12090 & $-0,00785$ & 0,00006157 & 0,10194 & 0,11970 & $-0,01776$ & 0,00031529 & 1 \\
\hline 29 & 0,11305 & 0,11930 & $-0,00952$ & 0,00009071 & 0,11149 & 0,11620 & $-0,00471$ & 0,00002218 & 1 \\
\hline 30 & 0,10978 & 0,11650 & $-0,01450$ & 0,00021025 & 0,11024 & 0,11930 & $-0,00906$ & 0,00008211 & 1 \\
\hline 31 & 0,10200 & 0,12040 & $-0,01743$ & 0,00030396 & 0,10074 & 0,12010 & $-0,01936$ & 0,00037472 & 1 \\
\hline \multirow[t]{3}{*}{32} & 0,10297 & 0,12020 & $-0,12020$ & 0,01444804 & 0,10381 & 0,12090 & $-0,01709$ & 0,00029218 & 1 \\
\hline & & & SSE & 1,65109127 & & & SSE & 0,23128999 & \multirow{2}{*}{$94 \%$} \\
\hline & & & MSE & 0,05159660 & & & MSE & 0,00722781 & \\
\hline
\end{tabular}

Keterangan :

1=Benar $\quad 0=$ Salah

Pada tabel 5 dapat dilihat perbandingan dari 5 model arsitektur jaringan yang digunakan. Dari ke 5 model arsitektur ini, tingkat Epoch dan waktu diperoleh dengan menggunakan aplikasi Matlab, sedangkan MSE dan Akurasi dari masingmasing model arsitektur diperoleh dengan menggunakan perhitungan pada Microsoft Excel. Model arsitektur terbaik adalah 5-18-1 yang menghasilkan tingkat akurasi yang sama sebesar 94\%.

Tabel 5. Perbandingan Akurasi Model Arsitektur Backpropagation

\begin{tabular}{ccccccc}
\hline \multirow{2}{*}{ No } & \multirow{2}{*}{ Arsitektur } & \multicolumn{3}{c}{ Training } & \multicolumn{2}{c}{ Testing } \\
\cline { 3 - 7 } & & Epoch & Waktu & MSE & MSE & Akurasi \\
\hline 1 & $5-8-1$ & 5978 & $1: 33$ & 0,000999858 & 0,002536222 & $84 \%$ \\
2 & $5-10-1$ & 6262 & $1: 38$ & 0,049458460 & 0,038720990 & $72 \%$ \\
3 & $5-15-1$ & 1285 & $0: 28$ & 0,000999007 & 0,007851080 & $47 \%$ \\
4 & $5-18-1$ & 855 & $0: 17$ & 0,051596602 & 0,007227812 & $94 \%$ \\
5 & $5-20-1$ & 2000 & $0: 37$ & 0,001000131 & 0,026721617 & $88 \%$ \\
\hline
\end{tabular}

\section{SIMPULAN}


Berdasarkan uraian hasil pembahasan sebelumnya dapat disimpulkan bahwa dari 5 model arsitektur yang digunakan antara lain : 5-8-1, 5-10-1, 5-15-1, 5-18-1 dan 5-20-1, diperoleh model arsitektur terbaik, yakni model 5-18-1 yang dapat melakukan prediksi dengan akurasi 94\%. Epoch serta waktu model arsitektur 5-18-1 juga lebih kecil (cepat) dibandingkan dengan 4 model arsitektur yang lain.

\section{DAFTAR PUSTAKA}

[1] I. Subekti, N. Khumaida, S. W. Ardie, and M. Syukur, "Evaluasi Hasil dan Kandungan Pati Mutan Ubi Kayu Hasil Iradiasi Sinar Gamma Generasi M 1 V 4," Jurnal Agron Indonesia, vol. 46, no. April, pp. 64-70, 2018.

[2] F. S. Pramesti, E. S. Rahayu, and Agustono, "Analisis Daya Saing Ubi Kayu Indonesia Di Pasar Internasional," Jurnal SEPA, vol. 14, no. 1, pp. 1-7, 2017.

[3] N. Zuraida, "Karakterisasi Beberapa Sifat Kualitatif dan Kuantitatif Plasma Nutfah Ubi Kayu ( Manihot esculenta Crantz .)," Buletin Plasma Nutfah, vol. 16, no. 1, pp. 49-56, 2010.

[4] A. Wanto, "Optimasi Prediksi Dengan Algoritma Backpropagation Dan Conjugate Gradient Beale-Powell Restarts," Jurnal Teknologi dan Sistem Informasi, vol. 3, no. 3, pp. 370-380, 2018.

[5] A. Wanto et al., "Levenberg-Marquardt Algorithm Combined with Bipolar Sigmoid Function to Measure Open Unemployment Rate in Indonesia," 3rd International Conference of Computer, Environment, Agriculture, Social Science, Health Science, Engineering and Technology, pp. 1-7, 2018.

[6] M. A. P. Hutabarat, M. Julham, and A. Wanto, "Penerapan Algoritma Backpropagation Dalam Memprediksi Produksi Tanaman Padi Sawah Menurut Kabupaten/Kota di Sumatera Utara," Jurnal semanTIK, vol. 4, no. 1, pp. 77-86, 2018.

[7] M. Fauzan et al., "Epoch Analysis and Accuracy 3 ANN Algorithm Using Consumer Price Index Data in Indonesia," in 3rd International Conference of Computer, Environment, Agriculture, Social Science, Health Science, Engineering and Technology, 2018, pp. 1-7.

[8] A. Wanto, "Penerapan Jaringan Saraf Tiruan Dalam Memprediksi Jumlah Kemiskinan Pada Kabupaten/Kota Di Provinsi Riau," Kumpulan jurnaL Ilmu Komputer (KLIK), vol. 5, no. 1, pp. 61-74, 2018.

[9] A. P. Windarto, L. S. Dewi, and D. Hartama, "Implementation of Artificial Intelligence in Predicting the Value of Indonesian Oil and Gas Exports With BP Algorithm," International Journal of Recent Trends in Engineering \& Research (IJRTER), vol. 3, no. 10, pp. 1-12, 2017.

[10] S. Putra Siregar and A. Wanto, "Analysis Accuracy of Artificial Neural Network Using Backpropagation Algorithm In Predicting Process (Forecasting)," International Journal Of Information System \& Technology, vol. 1, no. 1, pp. 34-42, 2017.

[11] A. P. Windarto, D. Hartama, and N. Dalimunthe, "Model Arsitektur Backpropogation Dalam Memprediksi Faktor Tunggakan Uang Kuliah (Studi Kasus AMIK Tunas Bangsa)," in Seminar Nasional Multidisiplin, 2017, pp. 1-9.

[12] A. Wanto, M. Zarlis, Sawaluddin, D. Hartama, J. T. Hardinata, and H. F. Silaban, "Analysis of Artificial Neural Network Backpropagation Using Conjugate Gradient Fletcher Reeves In The Predicting Process," Journal of Physics: Conference Series, vol. 930, no. 1, pp. 1-7, 2017.

[13] A. Wanto et al., "Analysis Of Standard Gradient Descent With GD Momentum And Adaptive LR For SPR Prediction," in International Conference of Computer, Environment, Agriculture, Social Science, Health Science, Engineering and Technology (3rd ICEST), 2018, pp. 1-9.

[14] A. Wanto and A. P. Windarto, "Analisis Prediksi Indeks Harga Konsumen Berdasarkan Kelompok Kesehatan Dengan Menggunakan Metode Backpropagation," Jurnal \& Penelitian Teknik Informatika Sinkron, vol. 2, no. 2, pp. 37-43, Oct. 2017.

[15] Solikhun, A. P. Windarto, Handrizal, and M.Fauzan, "Jaringan Saraf Tiruan Dalam Memprediksi Sukuk Negara Ritel Berdasarkan Kelompok Profesi Dengan Backpropagation Dalam Mendorong Laju Pertumbuhan Ekonomi," Kumpulan jurnaL Ilmu Komputer (KLIK), vol. 4, no. 2, pp. 184-197, 2017.

[16] A. P. Windarto, "Implementasi JST Dalam Menentukan Kelayakan Nasabah Pinjaman Kur Pada Bank Mandiri Mikro Serbelawan Dengan Metode Backpropagation," Jurnal Sains 
Komputer \& Informatika (J-SAKTI), vol. 1, no. 1, pp. 12-23, 2017.

[17] Sumijan, A. P. Windarto, A. Muhammad, and Budiharjo, "Implementation of Neural Networks in Predicting the Understanding Level of Students Subject," International Journal of Software Engineering and Its Applications, vol. 10, no. 10, pp. 189-204, 2016.

[18] A. Wanto, A. P. Windarto, D. Hartama, and I. Parlina, "Use of Binary Sigmoid Function And Linear Identity In Artificial Neural Networks For Forecasting Population Density," International Journal of Information System \& Technology, vol. 1, no. 1, pp. 43-54, 2017.

[19] E. Hartato, D. Sitorus, and A. Wanto, "Analisis Jaringan Saraf Tiruan Untuk Prediksi Luas Panen Biofarmaka di Indonesia," Jurnal semanTIK, vol. 4, no. 1, pp. 49-56, 2018.

[20] R. E. Pranata, S. P. Sinaga, and A. Wanto, "Estimasi Wisatawan Mancanegara Yang Datang ke Sumatera Utara Menggunakan Jaringan Saraf," Jurnal semanTIK, vol. 4, no. 1, pp. 97-102, 2018. 